\title{
Lög um brottnám líffæra við andlát
}

Meðal merkustu framfara læknisfræðinnar er flutningur líffæris frá líffæragjafa í annan einstakling sem pjáist af alvarlegri líffærabilun. Meðferðin getur bjargað lífi sjúklinga eða bætt lífsgæði peirra verulega og prátt fyrir að eiga sér ekki langa sögu hefur hún verið í mikilli frampróun og er enn. Fjöldi peirra sem purfa á líffærum að halda eykst stöðugt en framboð hefur ekki aukist að sama skapi. ${ }^{1}$ Líffæragjöf frá látnum einstaklingi er möguleg ef hann hefur verið úrskurðaður látinn samkvæmt skilmerkjum heiladauða og ljóst er að heilastarfsemi hefur stöðvast á óafturkræfan hátt. Helstu orsakir pess eru heilablóðföll eða alvarlegar heilaskemmdir vegna höfuðáverka. Árið 1991 sampykkti Alpingi lög um að nema mætti brott líffæri úr líkama einstaklings að honum látnum ef hann hefði lýst yfir vilja til pess í lifanda lífi en ef slík yfirlýsing væri ekki fyrir hendi pyrfti sampykki nánustu ættingja. ${ }^{2}$ Grunnur að peim lögum var pví „ætluð neitun“. Samtímis var sett fram reglugerð um hvernig úrskurða skyldi einstakling látinn samkvæmt heiladauðaskilmerkjum. Pessi lög gerðu líffæragjafir mögulegar hér á landi. Í slíkum tilfellum kemur teymi lækna og hjúkrunarfræðinga frá erlendu samningssjúkrahúsi og sér um brottnám líffæra en allur undirbúningur er í höndum íslensks heilbrigðisstarfsfólks. Líffæragjafir hafa að meðaltali verið um prjár á ári (um 10 líffæragjafir á milljón íbúa), ${ }^{3}$ nokkru færri en í nágrannalöndum okkar. Fyrstu árin höfnuðu aðstandendur líffæragjöf í 40\% tilfella en pað hlutfall hefur farið lækkandi á síðustu árum og líffæragjöfum hefur fjölgað.

Mörg Evrópulönd hafa breytt lagasetningu á pann hátt að gert er ráð fyrir „ætluðu sampykki“ einstaklinga fyrir líffæragjöf nema viðkomandi hafi áður lýst sig andvígan pví. Hefur petta til dæmis verið gert í Svípjóð, Finnlandi, Austurríki, Noregi, Belgíu, Frakklandi og á Spáni sem fyrstur landa gerði pessa lagabreytingu. ${ }^{4}$ Hlutfallslega er fjöldi líffæragjafa mestur á Spáni, eða 35 á hverja milljón íbúa á ári. Almennt hefur ekki verið sýnt fram á að lagabreytingin hafi fjölgað líffæragjöfum en lagasetningin staðfestir pjóðfélagssátt um að líffæri frá látnum einstaklingum skuli grædd í sjúklinga sem á purfa að halda. Yfirgnæfandi meirihluti Íslendinga (80\%) er hlynntur löggjöf um ætlað sampykki samkvæmt niðurstöðum rannsóknar sem birt var í Læknablaðinu 2014 og í peirri rannsókn lýstu 84\% sig viljuga til að gefa eigin líffæri við andlát sitt. Aðeins $5 \%$ höfðu pó skráð pann vilja sinn. ${ }^{5}$
Nýlega var sampykkt á Alpingi breyting á lögum um brottnám líffæra pannig að nema megi brott líffæri úr látnum einstaklingi og nota við læknismeðferð annars einstaklings, hafi hinn látni ekki lýst sig andvígan pví í lifanda lífi. Grunnurinn að peim lögum er pví ætlað sampykki. Nýju lögin munu taka gildi 1. janúar 2019. Með pessu er stigið mikilvægt framfaraskref í líffæragjafamálum og er í raun pjóðinni til sóma. Frumvarpið var sampykkt af miklum meirihluta pingmanna og enginn var andvígur pví. Í íslensku lögunum er skýrt tekið fram að ekki megi nema brott líffæri einstaklings leggist nánasti vandamaður gegn pví. Par með er staðfest sú regla sem viðhöfð hefur verið hér á landi og víðast annars staðar að ekki er farið gegn vilja ættingja. Lagabreytingin auðveldar heilbrigðisstarfsfólki öll samskipti við aðstandendur einstaklings sem hlotið hefur óafturkræfa stöðvun á heilastarfsemi auk pess sem hún ætti að auðvelda aðstandendum að taka ákvörðun fyrir hönd hins látna. Ef náinn aðstandandi er mótfallinn líffæragjöf er fullt tillit tekið til peirrar afstöðu.

Líffæragjöf er dýrmætasta gjöf sem við getum gefið öðrum og dæmi eru um að einn látinn einstaklingur hafi bjargað lífi eða bætt verulega lífsgæði sex annarra. Heiladauði er að sjálfsögðu hörmulegur atburður sem getur hent einstaklinga á öllum aldri en pað getur stundum verið aðstandendum huggun harmi gegn að geta hjálpað öðrum í neyð pegar slíkar aðstæður koma upp og mikilvægt að lagaumhverfi okkar auðveldi allan framgang pess. Í peim tilgangi er pessi lagabreyting afar mikilvæg en kynna parf mikilvægi líffæragjafar fyrir almenningi og huga vel að skipulagi og umgjörð starfseminnar í heilbrigðiskerfinu. Einnig er afar mikilvægt að hver og einn ákveði með sjálfum sér hvaða viðhorf hann hefur til líffæragjafar og kynni afstöðu sína fyrir sínum nánustu eða skrái ákvörðun sína á heimasíðu Embættis landlæknis.

\section{Heimildir}

1. Tullius SG, Rabb HN. Improving the Supply and Quality of DeceasedDonor Organs for Transplantation. N Engl J Med 2018; 378: 1920-9.

2. Lög um ákvörðun dauða, nr. 15/1991 og lög um brottnám líffæra, nr. $16 / 1991$.

3. Kárason S, Jóhannsson R, Gunnarsdóttir K, Ásmundsson P, Sigvaldason K. Líffæragjafir á Íslandi 1992-2002. Læknablaðið 2005; 91: 417-22.

4. Rithalia A, McDaid C, Suekarran S, Myers L, Sowden A. Impact of presumed consent for organ donation rates: a systematic review. BMJ 2009; 338: a3162.

5. Rúnarsdóttir K, Ólafsson K, Arnarson Á. Viðhorf Íslendinga til ætlaðs sampykkis við líffæragjafir. Læknablaðið 2014; 100: 521-5.

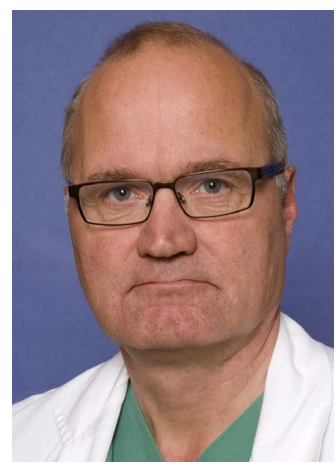

\section{Kristinn \\ Sigvaldason}

svæfinga- og gjörgæslulæknir á Landspítala

Fossvogi

krisig@landspitali.is

\section{Presumed consent for organ donation in Iceland}

Kristinn Sigvaldason MD Head of Intensive care, Landspitali University Hospital, Reykjavík, Iceland

doi.org/10.17992/lbl.2018.0708.190 